\title{
Management Strategies for Improving the Functionality of Tertiary Education in Nigeria
}

\author{
Dr. Romina Ifeoma Asiyai ${ }^{1} \&$ Patience Okoro ${ }^{2}$ \\ ${ }^{1}$ Department of Educational Management and Foundations Delta State University, Abraka, Nigeria \\ ${ }^{2}$ Post Graduate Student, Department of Educational Management and Foundations Delta State University, Abraka, \\ Nigeria \\ Correspondence: Dr. Romina Ifeoma Asiyai, Department of Educational Administration and Policy Studies Delta \\ State University, Abraka, Nigeria. E-mail: asiyairomina@yahoo.com
}

Received: June 3, 2019

Accepted: July 10, 2019

Online Published: July 13, 2019

doi:10.5430/ijhe.v8n4p108

URL: https://doi.org/10.5430/ijhe.v8n4p108

\begin{abstract}
This study investigates management strategies for improving the functionality of tertiary education in Nigeria. One research question was asked and answered and three hypotheses were formulated and tested at 0.05 alpha level. The sample of the study comprised 900 respondents selected through the simple random sampling technique from six tertiary institutions in Delta and Edo States of Nigeria. The questionnaire was the instrument for collection of data from the respondents. Descriptive statistics in the forms of mean and standard deviation were used to answer the only research question. The three hypotheses were tested using one way analysis of variance. The results obtained showed that improved funding, monitoring and adoption of best practice in service delivery would help to improve the functionality of tertiary education in Delta and Edo States. Staffs of University, Polytechnics and Colleges of Education did not differ significantly in their mean perception scores for any of the identified management strategy for improving the functionality of tertiary education. The study recommended that governments of Delta and Edo States should give adequate priority to tertiary education by ensuring that enough fund is allocated and disbursed to the institutions for proper management of affairs and improved functionality.
\end{abstract}

Keywords: Delta, Edo, functionality, management, strategies, tertiary education

\section{Introduction}

Education is the greatest tool for enhancing the development and sustainability of nations. Education can enhance sustainable development of nations if it is functional. Functional education lays more emphasis on recipient's ability to put into practice what is learnt. The functionality of education is dependent on the extent to which the recipients can effectively use their hearts, heads, and hand to contribute to socio-economic, technological, scientific, and political development of a nation. For education to be functional and enhance national development, it must be of good quality and high standards. This is because the correlation between quality of education and production of skilled manpower capable of fostering national development the optimal productivity of the recipients is of paramount important in functional education.

Functional education is the education that emphasizes the learners' interests and needs. Such education is conducted in a lively school environment that triggers the leaner to act enthusiastically. The curriculum of functional education must be learner-centered. Functional education is the education that empowers the learners with relevant knowledge, values, skills and competences required for productive task performance (Asaju and Adagba, 2014). Functional education enables the learners to put into practice what was learnt in theory. The individual who received functional education has immediate meaning which can be transferred into action in the learning process (Asju and Adagba, 2014). Additionally, the functionality of education is the extent to which the education received by learners improves or changed their attitudes, values, knowledge, feelings, skills and behaviour. Students who receive functional education should be able to utilize and apply knowledge learnt in solving problems that hitherto impeded their progress in life.

Education becomes dysfunctional when it does not meet the knowledge and skills needs of learners, thus making them not capable of performing in real life situations. Functional tertiary education is the basic or fundamental vehicle for addressing or combating unemployment, hunger and poverty as well as improving the quality of life of 
mankind. According to Asaju \& Adagba, (2014) functional education will usher in high level manpower that is capable of turning available resources into wealth for Nigeria.

Most developed countries invest heavily on their education sector because of the recognition of the role of education in piloting national development. Suffix to say that the difference between developed and developing countries of the world lies on the functionality of their educational system. While the governments of most developed countries are committed to making their education system functional by ensuring that education is adequately provided for in their national budget, developing countries especially Nigeria, the government pays less attention to education. A good example is the Central Bank of Nigeria (CBN, 2017), report which indicated that within a period of ten years 2008-2017 the percentage of naira allocated to education in Nigeria is 11.0, 6.54, 6.60, 7.30, 10.0, 8.7, 10.0, 9.00, 6.00 , and 6.00 respectively. From these figures, it is clear that the government of Nigeria has been neglecting the education sector. The Nigerian government has not been able to meet up with the standard recommended (26\% of GDP) globally for allocation to education by UNESCO. Allocation to education sector dropped drastically in 2016 and 2017 during recession. This drastic drop in financial allocation to education has short chained the tertiary education.

The attainment of excellent, efficient and quality functional tertiary education adequate funding is imperative. Government of Nigeria expects administrators of institutions to look inward for additional sources of income. These additional sources of internally generating revenue for smooth management of affairs of tertiary institutions in Nigeria have continued to dwindle. Additionally, tertiary institutions in the country have not been creative to engineer other ways of fund creation for smooth administration of the institutions. .Sources like weekend degree and sandwich programmes which hitherto were sources from which universities generated funds for successful management of the institution have been scrapped in some universities due to government policies. Adamu (nd) noted that the dilapidation of facilities and dwindling resources in universities in Nigeria were serious factors that acted as demoralizers of staff in pursuing quality delivery of services.

Presently, the world is tech-driven. As a result, tertiary education system in Nigeria needs to be re-structured to meet the current realities. The aim is to make the system optimally function within the exigencies of a globalized world. The 6-3-3-4 education policy in Nigeria was meant to inject functionality into Nigerian education system but it failed. This has led to the skewed emphasis on entrepreneurship education (Akintuoku, 2006). In addition the federal government introduced 34 trade subjects at the secondary education level. According to NERDC (2011) cited in Alabi (2014), the 6-3-3-4 programme failed for want of relevance and epistemological inadequacy. The current entrepreneurial drive in institutions of higher learning is the best practice to making education more functional in Nigeria. Okojie cited in Nwekeaku (2013) believed that through entrepreneurship education which will equip students with skills, social vices such as examination malpractice, cultism and moral decadence will be reduced. This study examined strategies for managing tertiary education in Nigeria for enhanced functionality and national development.

\subsection{Statement of the Problem}

Functionality of any education system lies in the ability of the graduates of that education system being able to put in practice what was learnt. The learner's ability to utilize and apply what was learnt in solving problems depend on pedagogical methodology and the richness of the learning experiences they were exposed to. In addition, the teacher's ability to expose students to relevant knowledge depends on his/her qualification, knowledge and experiences and the resources provided for teaching and learning. The challenges of the 21 st century require individuals who are sufficiently skilled and possess relevant knowledge. This requires proper management of education so as to make teaching and learning more functional. This area has not received much attention in research in Nigeria. Hence this investigation is deemed necessary.

\subsection{Research Questions}

The following questions are posited and answered in this study;

What strategies could be adopted for managing tertiary education in Nigeria for enhancing its functionality?

\subsection{Hypothesis}

The following hypothesis is formulated and tested at 0.05 significant level;

There is no significant difference among the mean perception scores of respondents from Universities, Polytechnics and Colleges of Education on funding, monitorin and best practice as strategies for managing tertiary education for enhancing its functionality in Delta and Edo States of Nigeria. 


\section{Methodology}

The study population comprises all public tertiary institutions in Delta and Edo States during the 2017/2018 academic session. The sample for the study comprises 900 respondents drawn from two Universities, two Polytechnics and two Colleges of Education in Delta and Edo States of Nigeria. Simple random sampling technique was employed in selecting 400 respondents from the two selected Universities, 260 respondents from the two Polytechnics and 240 respondents from the two selected Colleges of Education. The sample is broken as follows: students $=300$, senior non-academic staff $=240$ and academic staff $=360$.

Questionnaire was the instrument used for the collection of data from the respondents. It has four segments. The first segment contains the demographic data of the respondents such as name of institution, location and academic status of respondents. The second segment of the instrument contains ten items eliciting information on funding strategies for managing tertiary education for enhanced functionality. The third segment contains six items which elicit information on monitoring strategies for managing tertiary education for enhanced functionality. The fourth segment contains ten items which elicits information on best practice strategies for managing tertiary education for enhanced functionality.

The face and content validity of the instrument was censured by two Professors of educational administration who read through the items and provided suggestions that were used in fine tuning the instrument before the final copies were printed. The reliability of the instrument was determined using test re-test method. Copies of the instrument were administered to thirty staff of three tertiary institutions in Anambra state. The exercise was repeated after two weeks. Pearson Product Moment formula was employed in computing the reliability of the instrument. Reliability indexes of $0.43,0.50$ and 0.45 were obtained respectively for the three sets of questionnaire. The values were stopped up by using Spearman Brown formula to yield reliability indexes of $0.68,0.70$ and 0.77 for funding, monitoring and best practice strategies questionnaires respectively. In this way the items stability was ascertained. The researcher and five research assistants administered the instrument to the respondents in the six tertiary institutions used for the study. Out of 900 copies of the instrument administered, 860 were returned good enough and used for analysis of data. The research questions were answered using mean and standard deviation. The three hypotheses were tested using one way analysis of variance at 0.05 alpha level. The cut-off point for arriving at decision to accept or not to accept an item is 2.50 .The 2.50 is the product of the summation of the four points scale divided by 4 . That is $4+3+2+1=10 / 4=2.50$. Items whose mean score are 2.50 and above are accepted but those items with mean score below 2.50 were not accepted. 


\section{Results}

Table 1. Mean Perception Scores of Respondents on Funding as a Strategy for Improving Functionality of Tertiary Education

\begin{tabular}{|c|c|c|c|c|c|c|c|c|}
\hline \multicolumn{3}{|c|}{ Universities } & \multicolumn{3}{|c|}{ Polytechnics } & \multicolumn{3}{|c|}{ Colleges of Education } \\
\hline Mean & SD & Remark & Mean & $\mathrm{SD}$ & Remark & Mean & $\mathrm{SD}$ & Remark \\
\hline 2.96 & 0.74 & + & 2.79 & 0.72 & + & 2.97 & 0.46 & + \\
\hline 3.15 & 0.67 & + & 2.94 & 0.87 & + & 2.99 & 0.45 & + \\
\hline 3.30 & 0.70 & + & 3.17 & 0.73 & + & 3.03 & 0.45 & + \\
\hline 2.85 & 1.05 & + & 2.93 & 0.86 & + & 2.85 & 0.71 & + \\
\hline 3.44 & 0.65 & + & 3.38 & 0.55 & + & 3.43 & 3.35 & + \\
\hline 3.18 & 0.73 & + & 3.08 & 0.66 & + & 2.94 & 0.59 & + \\
\hline 3.29 & 0.74 & + & 3.26 & 0.72 & + & 3.06 & 0.56 & + \\
\hline 3.29 & 0.75 & + & 3.20 & 0.65 & + & 3.04 & 0.45 & + \\
\hline 3.07 & 0.81 & + & 3.19 & 0.66 & + & 2.99 & 0.54 & + \\
\hline 2.94 & 0.85 & + & 2.89 & 0.88 & + & 2.82 & 0.65 & + \\
\hline 3.32 & 0.78 & + & 3.23 & 0.89 & + & 3.00 & 0.58 & + \\
\hline 3.29 & 0.59 & + & 3.27 & 0.57 & + & 3.13 & 0.40 & + \\
\hline 2.78 & 0.87 & + & 2.97 & 0.90 & + & 2.63 & 0.75 & + \\
\hline 2.94 & 0.77 & + & 3.04 & 0.68 & + & 3.22 & 3.46 & + \\
\hline 2.75 & 0.81 & + & 2.67 & 0.87 & + & 2.56 & 0.67 & + \\
\hline 3.07 & 0.65 & + & 3.13 & 0.69 & + & 2.98 & 0.49 & + \\
\hline 3.23 & 0.70 & + & 3.23 & 0.69 & + & 2.98 & 0.55 & + \\
\hline 3.05 & 0.63 & + & 3.01 & 0.60 & + & 2.86 & 0.49 & + \\
\hline 3.13 & 0.73 & + & 3.25 & 0.64 & + & 3.00 & 0.49 & + \\
\hline 2.60 & 0.84 & + & 2.61 & 0.89 & + & 2.64 & 0.66 & + \\
\hline 2.45 & 0.84 & - & 2.56 & 0.94 & + & 2.55 & 0.61 & + \\
\hline 2.43 & 0.79 & - & 2.34 & 0.84 & - & 2.44 & 0.64 & - \\
\hline 2.09 & 0.83 & - & 2.04 & 0.78 & - & 2.26 & 0.69 & - \\
\hline 2.26 & 0.86 & - & 2.25 & 0.93 & - & 2.30 & 0.77 & - \\
\hline 2.54 & 0.87 & + & 2.57 & 0.87 & + & 2.67 & 0.66 & + \\
\hline 2.28 & 1.79 & - & 2.63 & 2.86 & + & 2.33 & 0.74 & - \\
\hline 2.91 & 0.81 & + & 2.91 & 0.84 & + & 2.83 & 0.80 & + \\
\hline
\end{tabular}

Decision is arrived at using 2.50 as bench mark for accepting an item or not accepting an item. An item with positive (+) sign indicates agreed while those having negative (-) sign indicate disagreed. Majority of the items in Table 1 have positive signs. Thus, the corresponding items are the strategies for managing tertiary education for improving its functionality. 


\subsection{Testing of Hypothesis}

Table 2. Summary of one way analysis of variance showing the difference between mean scores of the response from the three institutions

ANOVA

\begin{tabular}{|c|c|c|c|c|c|c|}
\hline & Sum of Square & df & $\begin{array}{l}\text { Mean } \\
\text { Square }\end{array}$ & $\mathbf{F}$ & & Sig \\
\hline Between Groups & .983 & 2 & .492 & \multirow{2}{*}{5.835} & & \multirow{2}{*}{.003} \\
\hline Within Groups & 72.212 & 857 & .084 & & & \\
\hline Total & 73.195 & 859 & & & & \\
\hline \multicolumn{7}{|l|}{ Multiple Comparisons } \\
\hline \multicolumn{7}{|c|}{ Dependent Variable: Strategies for Improving Functionality of Tertiary Education } \\
\hline \multicolumn{7}{|l|}{ Tukey HSD } \\
\hline & & & & \multicolumn{3}{|c|}{ 95\% Confidence Interval } \\
\hline (I) Institution & (J) Institution & $\begin{array}{l}\text { Mean } \\
\text { Difference (I-J) }\end{array}$ & $\begin{array}{l}\text { Std. } \\
\text { Error }\end{array}$ & Sig. & $\begin{array}{l}\text { Lower } \\
\text { Bound }\end{array}$ & Upper Bound \\
\hline \multirow[t]{2}{*}{ Universities } & Polytechnics & .00249 & .02370 & .994 & -.0531 & .0581 \\
\hline & $\begin{array}{l}\text { Colleges of } \\
\text { Education }\end{array}$ & $.07713^{*}$ & .02419 & .004 & .0203 & .1339 \\
\hline \multirow[t]{2}{*}{ Polytechnics } & Universities & -.00249 & .02370 & .994 & -.0581 & .0531 \\
\hline & $\begin{array}{l}\text { Colleges } \\
\text { Education }\end{array}$ & $.07465^{*}$ & .02651 & .014 & .0124 & .1369 \\
\hline \multirow[t]{2}{*}{ Colleges of Education } & Universities & $-.07713^{*}$ & .02419 & .004 & -.1339 & -.0203 \\
\hline & Polytechnics & $-.07465^{*}$ & .02651 & .014 & -.1369 & -.0124 \\
\hline
\end{tabular}

*. The mean difference is significant at the 0.05 level.

The result in the table indicates there is a significant difference between the mean scores of respondents from the three institutions on the strategies for improving the functionality of tertiary education in Nigeria. Further post-hoc analysis using Tukey HSD revealed that the mean score for university staff 2.91, SD 0.27) is higher than that of Polytechnics (2.91 $(, \mathrm{SD}=0.30)$ and Colleges of Education $(2.83, \mathrm{SD}=0.30)$. Therefore the difference lies between Universities and Colleges of Education and Polytechnics and Colleges of Education.

\section{Discussion}

The result for the research question reveals that staff of Universities, Polytechnics and Colleges of Education in the two states agree that funding is a strategy for improving the functionality of tertiary education in that States. The respondents agree that government adhering to the UNESCO recommended $26 \%$ budgetary allocation to education can help facilitate proper funding of tertiary education in the States for improved functionality. They further said that with adoption of adequate funding strategy administrators of institutions would be able to provide stimulating environment for skills training of students, put in place laboratories and workshops for improved students' learning and teaching, as well as purchase good journals, current and relevant textbooks and other facilities for functional teaching and learning. The respondents also expressed the opinion curriculum review in line with skills and knowledge needs of the nation and provision of consumables for daily administration of affairs of the institutions are possible with proper funding strategy. With enough funding of tertiary education in Nigeria, administrators of the institutions would be able to put in place e-journals, e-library, carry out staff development as well as carry out curricula review in line with skills and knowledge needs of the nation. Students learn meaningfully when the facilities and resources for learning are adequate and functional. With well equipped laboratories and workshops practical works can be properly conducted on a regular basis for students' meaningful learning and academic development and training to meet market demands. Kyoshaba (2009) found that university facilities and quality of lecturers were important determinants of students learning. Additionally, the finding on funding has the support of Ebereghwa (2016) that addressing the challenges of universities such as inadequate infrastructure, library facilities, under staffing and almost-complete neglect of research would require adequate funding of higher education. In 
addition, Okoye (2016) stressed that enrolment into higher education in Nigeria have continued to increase without commensurate increase in infrastructure, workshops, libraries and other physical facilities for meaningful teaching, learning and research. Okoye (2016) maintained that tertiary education in Nigeria have suffered continued decline in funding which have incapacitated the institutions in meeting up the challenges of staff recruitment, improvement of facilities for attainment of quality and functional education.

The respondents further attested that monitoring strategies can help improve the functionality of tertiary education in the two States. They expressed the view that regular monitoring of lecture attendance by lecturers and use of monitoring teams to check mate lecturers' lecture attendance can help improve the functionality of tertiary education. They also agree that monitoring the strict implementation of $75 \%$ lecture attendance before a student is allowed to write semester examination can improve the functionality of the tertiary education system. The respondents further expressed that regular monitoring of academic activities and prompt provision of feedback to lecturers can help in improving the quality and functionality of the system. They additionally said that unethical conducts of staff and students can be minimized for improved functionality of tertiary institutions in the two States through monitoring. This finding has the support of Ndugu, Gathu, and Bumett, (2015) that monitoring can help in improving the quality and functionality of school programmes.

Similarly, the respondents agreed that adopting best practice in conducting academic activities is a strategy for improving the functionality of tertiary institutions in the two states Application of best practice in activities and functions of tertiary institutions including admission of students, teaching and learning, research, appointment of staff, promotion of staff as well as provision of facilities and materials for service delivery and conflict resolution would help in improving the functionality of tertiary institutions in Delta and Edo States, Nigeria. This finding lend credence with Ikoya (2016) that global best practice in admission of students into universities led to improvement in quality assurance in the system. When global best practice is followed in the admission process, only the best and qualified students will be admitted. Politicians would not interfere in the admission process by using admission of low performing candidates as political gifts for their own interest. In this way, examination frau and malpractice would reduce and the functionality of tertiary education could become better.

\section{Conclusion}

This study examined the strategies for strategies for managing tertiary education in Delta and Edo States of Nigeria for enhanced functionality and national development. From the findings of the study, the conclusion that could be drawn is that the strategies are proper funding, supervision and monitoring as well as adopting best practice in conducting academic activities.

\section{Recommendations}

The study puts forward the following recommendations based on the findings:

1. Governments of Delta and Edo States of Nigeria should ensure that they properly fund tertiary institutions in the States by adhering to the UNESCO $26 \%$ budgetary allocation and disburse adequate funds to the institutions.

2. Administrators of tertiary institution in Delta and Edo States should ensure that they try out means of making the government to properly fund the institutions for effective management of affairs of the institutions for improved functionality and national development.

3. Administrators of tertiary institutions in Delta and Edo States should map out strategies of monitoring effectively the conduct of academic activities within the institutions to help improve the functionality of the institutions.

4. Administrators of tertiary institution in Delta and Edo States should ensure that they supervise teaching and learning regularly to help check mate lecture attendance by lecturers and thus improve students' learning.

5. Administrators of tertiary institution in Delta and Edo States should ensure that supervisory feedback is promptly made available to lecturers for improved delivery of lectures for better students' learning.

6. Administrators of tertiary institution in Delta and Edo States should ensure that they regularly adopt the best practice option in conducting academic activities in all ramifications.

7. Academic Staff Unions should brain storm on new ways of fund generation to help revive the tertiary institutions in Nigeria and inform the administrators. 


\section{References}

Adamu, A. U (nd ) Motionless point in chaos: education reforms, innovations and the challenges for higher education in Nigeria. Available at http://aadcice.hiroshima-u.ac.jp/e/reseach/paper_no8-1.pdf.

Akintuoku, N. N. (2006). The challenges of basic education in Nigeria: Post-independence experience. Retrieved from http://www.challengesinbasiceducationinnigeria.com

Alabi, F. O. (2014). Implementing the new secondary school curriculum for the realization of the objective of entrepreneurship education in Ondo State, Nigeria. European Scientific Journal, 1, 264-270.

Asaju, K. \& Adagba, S. O (2014). Functional education in Nigeria: A catalyst for effective poverty alleviation. Research Journal in Organizational Psychology and Educational Studies, 3(4), 313-318.

Retrieved from https://www.researchgate.net/publication/288823352_

CBN (2017). The state of education in Nigeria UNESCO http://unesdoc.unesco.org/images/0014/001495/149503eo.pdf.

Ebereghwa , P. O. M. (2016). "Forensic accounting and fraud examination as an aid to effective financial management in higher educational institutions in Nigeria". In E. P. Oghuvbu (ed) Global best practices in higher education for national development. A Book in honour of Prof. V. F. Peretomode. Abraka: Patola Technologies CO.

Ikoya, P. (2016). Global best practices in the administration of university admission for the $21^{\text {st }}$ century" In E. P. Oghuvbu (ed) Global best practices in higher education for national development. A Book in honour of Prof. V. F. Peretomode. Abraka: Patola Technologies CO.

Kyoshaba, M. (2009). Factors affecting academic performance of undergraduates at Uganda Christian University. Mater Dissertation, Makerere University, Uganda. Available at https://news.mak.ac.ug/documents/Makfiles/theses/Kyoshaba\%20Martha.pdf .

Ndugu, B. W., Gathu, A, and Bumett, E. (2015). Influence of monitoring and evaluation by principals on teaching and learning in Githunguri District, Kenya. Journal of Education and Practice, 6(9), 10-18. Available at: https://files.eric.ed.gov/fulltext/EJ1082461.pdf www.iiste.org.

Nwekeaku, C. (2013). Entrepreneurship education and challenges to Nigerian Universities. Journal of Education and Practice, 4(3). Available at http://pakacademicsearch.com/pdf-files/edu/413/51-6\%20Vol\%204,\%20No\%203\%20(2013).pdf

Okoye, N. S. (2016). "Re- engineering higher education curriculum in Nigeria for national development”. In E. P. Oghuvbu (ed) Global best practices in higher education for national development. A Book in honour of Prof. V. F. Peretomode. Abraka: Patola Technologies CO. 